\title{
BENEFITS OF HIGH STRENGTH MICROSILICA CONCRETE IN THE CONSTRUCTION OF TALL BUILDINGS
}

\author{
B Sealey ${ }^{1}$ \\ ${ }^{I}$ Elkem Silicon Materials, Norway
}

\begin{abstract}
This paper provides an overview of the benefits of using high strength microsilica concrete in the construction of tall buildings. Microsilica is an industrial co-product, arising as an ultra-fine powder. When added to a concrete mixture it can increase the strength of the concrete, by (a) pozzolanic reaction and (b) improved particle packing. Since the 1980s, microsilica has featured increasingly in the construction of tall buildings, as engineers have sought to optimise the design of tall buildings through the use of high strength concrete. By reviewing case studies of tall buildings constructed with high strength microsilica concrete, it is argued thathighstrength concretecan achieve significant economic advantages over conventional strength concrete. In many cases, it is evident that a 'triple-blend' approach to high strength concrete mix design, using Portland cement + microsilica + either fly ash or ground granulated blast furnace slag has enabled increased performance and improved sustainability.
\end{abstract}

Keywords: Microsilica, Silica Fume, High Performance Concrete, Tall Buildings, Durability, Sustainability

\section{INTRODUCTION}

Over the past 30 years, a large number of tall buildings have been constructedwith high strength microsilica concrete.

A key motivation for adopting high strength concrete in building design has been to reduce cost.

Generally, the cost of the additional materials required to increase the strength of a concrete mixture (i.e. microsilica and superplasticiser) will cause the price of the concrete mixture to increase. Although high strength concrete has higher material cost per unit volume, the higher compressive strength of the concrete means that column cross section can be reduced [1].Therefore the overall volume of concrete, formwork and reinforcement is reduced. The higher the concrete strength the more economical a column becomes.

Starting in the 1980s, microsilica has developed a reputation as one of the key materials enabling engineers to produce high strength concrete. This paper presents a review of microsilica technology and the benefits of high strength concrete in the construction of tall buildings.

\subsection{Properties of microsilica}

Microsilica, also known as silica fume,originates as a coproduct from the production of silicon or ferrosilicon.

Two key attributes of microsilicacan be highlighted:

- Small round particles (typically 0.1 to $0.3 \mu \mathrm{m}$ ) and a corresponding high specific surface area. These factors contribute to particle packing and to internal cohesion in the concrete mixture.

- High content of amorphous, and therefore reactive, silicon dioxide. The high specific surface area and reactive $\mathrm{SiO}_{2}$ makes microsilica an extremely efficient pozzolan - it consumes calcium hydroxide and reacts with alkalis in the concrete. This leads to less alkali in the pore solution and less calcium hydroxide in the matrix. Consequently, more calcium silicate hydrate binder is present and less calcium hydroxide.

Table 1[2] provides a comparison of the typical chemical and physical properties of microsilica, compared with fly ash and Ground Granulated Blast Furnace Slag (GGBS).

Table 1: Typical chemical and physical properties of microsilica, fly ash and GGBS [2]

\begin{tabular}{|l|l|l|l|}
\hline & Fly ash & GGBS & Microsilica \\
\hline Fineness $\left(\mathrm{m}^{2} / \mathrm{kg}\right)$ & 450 & 350 to 550 & 15000 to 30000 \\
\hline Specific gravity & 2.2 & 2.9 & 2.2 \\
\hline Silicon $\left(\%\right.$ as $\left.\mathrm{SiO}_{2}\right)$ & 38 to 55 & 30 to 40 & $>85$ \\
\hline Aluminium $\left(\%\right.$ as $\left.\mathrm{Al}_{2} \mathrm{O}_{3}\right)$ & 20 to 40 & 5 to 20 & $<2$ \\
\hline Iron $\left(\%\right.$ as $\left.\mathrm{Fe}_{2} \mathrm{O}_{3}\right)$ & 6 to 16 & $<2$ & $<1$ \\
\hline Calcium $(\%$ as $\mathrm{CaO})$ & 1.8 to 10 & 35 to 40 & $<1$ \\
\hline Loss on ignition $(\%)$ & 3 to 20 & $<3$ & $<4$ \\
\hline
\end{tabular}




\subsection{Effect of microsilica on the concrete mixture}

Well-dispersed microsilica particles which have packed around aggregate particles during concrete mixing and placing will modify the interfacial transition zone between the cementitious paste and the particles of aggregate. In conventional concrete, the microstructure of the transition zone is significantly different from that of the bulk paste. Modification of this transition zone is a major benefit of the addition of microsilica, as it gives increased strength to the concrete [3].

Microsilica helps to optimize the particle packing of aggregates and powders in the concrete mix design, helping to minimise the number of voids and increasing the density of the concrete. By improving packing, concrete properties including strength can be improved. To help design a concrete mixture with optimal particle packing, computer programs are available, for example the EMMA grading curve program [4], based on the Andreasen and Andersen mathematical model [5].

Microsilica concrete can be significantly more resistant than conventional concretes towards degradation caused by the ingress of aggressive ions or by leaching from the concrete. This is a consequence of an improved, more homogeneous, pore system giving reduced permeability to water and aggressive ions and improved resistance to leaching. In addition, microsilica can also cause a significant reduction in the electrical conductivity of concrete. This is beneficial because active corrosion (of steel within the concrete) is an electrochemical process, governed by the resistivity of the concrete. The practical consequence of these factors is that microsilica significantly reduces the risk of chlorideinitiated corrosion, especially in concrete exposed to severe environments.

Table 2:Comparison of embodied $\mathrm{CO}_{2}$ of main constituents of reinforced concrete, example from UK[2]

\begin{tabular}{|l|l|}
\hline Material & Embodied $\mathrm{CO}_{2}(\mathrm{~kg} /$ tonne $)$ \\
\hline Portland cement, CEM I & 930 \\
\hline GGBS & 52 \\
\hline Fly ash & 4 \\
\hline Limestone fines & 32 \\
\hline Microsilica powder & 28 \\
\hline Aggregate & 4 \\
\hline Reinforcement & 427 \\
\hline
\end{tabular}

\subsection{Supply of microsilica}

International Standards for microsilica include ASTM C 1240 [6] published by ASTM International and EN 13263 [7] published by European Committee for Standardization. For projects in India, microsilica specifiers can require compliance with IS 15388:2003 [8].
Microsilica is often supplied as a densified powder, with the ultra-fine microsilica particles loosely agglomerated together to aid handling. During mixing at the concrete plant, it is important to ensure the densified microsilica particles are fully dispersed throughout the concrete mixture. This can be achieved by a suitable batching regime with efficient mixing plant and adequate mixing time. The use of superplasticiser is essential to aid dispersion and achieve low water/binder ratio.

Microsilica arises as a co-product and has lower embodied carbon emissions than Portland cement. An example from the UK of a typical embodied carbon value for microsilica compared to Portland cement is in Table 2 [2].

\section{CASE STUDIES}

\subsection{0ne Island East}

One Island East in Hong Kong is a 70 floor commercial building. Completed in 2008, it was constructed using $32,000 \mathrm{~m}^{3}$ of Grade $100 \mathrm{MPa}$ concrete. The Grade 100 concrete mixturewas based on a triple blend of microsilica + fly ash + Portland cement, with microsilica comprising $10 \%$ mass of the blend. Chan et al [9] conducted a life cycle analysis of this building, and reported that the mix design used for the Grade 100 triple blend concrete, including fly ash $+10 \%$ microsilica, had a similar carbon footprint per unit volume to a typical conventional Grade 45 concrete. This is because the triple blend, and a low water/binder ratio, enabled the amount of Portland cement in the Grade 100 mix design to be an optimal low amount.

Chan et al [9] also found that the Grade 100 high strength concrete enabled a $30 \%$ reduction in the volume of concrete needed, compared to using a hypothetical Grade 45 concrete, and that "such reduction in the volume of concrete needed had significantly reduced the total cement consumption and thus the carbon footprint of the concrete construction."

\subsection{BurjKhalifa}

A tripleblend microsilica concrete mix was used during construction of the BurjKhalifa, which at 828 metres tall was the world's tallest building when officially opened in 2010. This project chose a tripleblend mixture to improve pumpabilityand also to achieve high strength.

Tripleblend concrete mixtures can exhibit greater overall durability performance than mixtures containing only Portland cement. Many researchers have previously documented the advantages of triple blends, including for example Thomas [10] who found that a microsilica + fly ash + Portland cement blend had increased resistance to chloride ion penetration, alkali-silica reaction, and sulfate attack. Thomas also reported improved placing and finishing characteristics and material cost savings compared with Portland silica fume cement. 
For the BurjKhalifa, the $80 \mathrm{MPa}$ superstructure concrete mix contained microsilica (10\% of binder), along with Fly Ash (13\% of binder) and specially selected admixtures. Designed to be almost self-consolidating in consistence, with slump flow typically $600 \mathrm{~mm}$, this mix was used until pumping pressure exceeded approximately 200 bar.

\subsection{Comfort Towers, Tokyo}

Completed in 2005, the West and East Comfort Towers in Tokyo are 153 and 178 metres tall respectively. High strength microsilica concrete was used in the columns in the lower eight floors of the East Tower and in the first floor columns in the West Tower. The columns are heavily reinforced and have an outer permanent steel mantle. This system, in combination with high strength concrete, gives maximum strength and rigidity to the structure to withstand the heavy loads of the building as well as earthquake stress. The highest strength mix used on this project achieved an average 28 day compressive cylinder strength of $131 \mathrm{MPa}$. A relatively high dose of microsilica was used in this mix $\left(80 \mathrm{~kg} / \mathrm{m}^{3}\right)$ combined with low water/binder ratio $(0.19)$

\subsection{Selected India examples}

- World One Tower, Mumbai. Grade M95 (Figure 1)

- $\quad$ Oasis Tower, Mumbai. Grade M70 (Figure 2)

\subsection{Selected early examples}

- The construction of the 186metre tallTrianon building in Frankfurt in 1990 using an $85 \mathrm{MPa}$ concretewas one of the first applications of high strength concrete in Germany. The concrete contained $6 \%$ microsilica. In a comparison of the costs of using the $85 \mathrm{MPa}$ high strength concrete against the hypothetical costs if $45 \mathrm{MPa}$ conventional strength had been used, Hegger[11] concluded that the $85 \mathrm{MPa}$ concrete was more economically efficient and highlighted the enlargement of rentable space that was made possible due to the reduced column dimensions.

- 311 South Wacker Drive in Chicago, USA was the world's tallest concrete structure on its completion in 1990. $85 \mathrm{MPa}$ high strength concrete was used to ensure that the same cross section of columns could be used throughout the building, thereby saving on formwork. In addition, the high early strength of the concrete mixture enabled faster construction.

- Scotia Plaza, a 68 floor office tower constructed in1986 and the first in Toronto to use high strength concrete [12]. The concrete had a specified strength of $70 \mathrm{MPa}$ at 91 days. The mix design had a total binder content of $470 \mathrm{~kg} / \mathrm{m}^{3}$ including $7.8 \%$ microsilica. Water/binder ratio was 0.31 and actual 91 day strengths exceeded $90 \mathrm{MPa}$.

\section{PUMPING}

Although the primary focus for using microsilica on a tall building project is often to achieve high strength, microsilica can also improve the handling properties of the fresh concrete mixture. When microsilica is added, the concrete mix becomes more cohesive and less prone to segregation. This is a beneficial effect, due to the spherical shape and high surface area of the microsilicaparticles. This aids pumpability and in addition, it can help make selfcompacting concrete mixtures more robust.

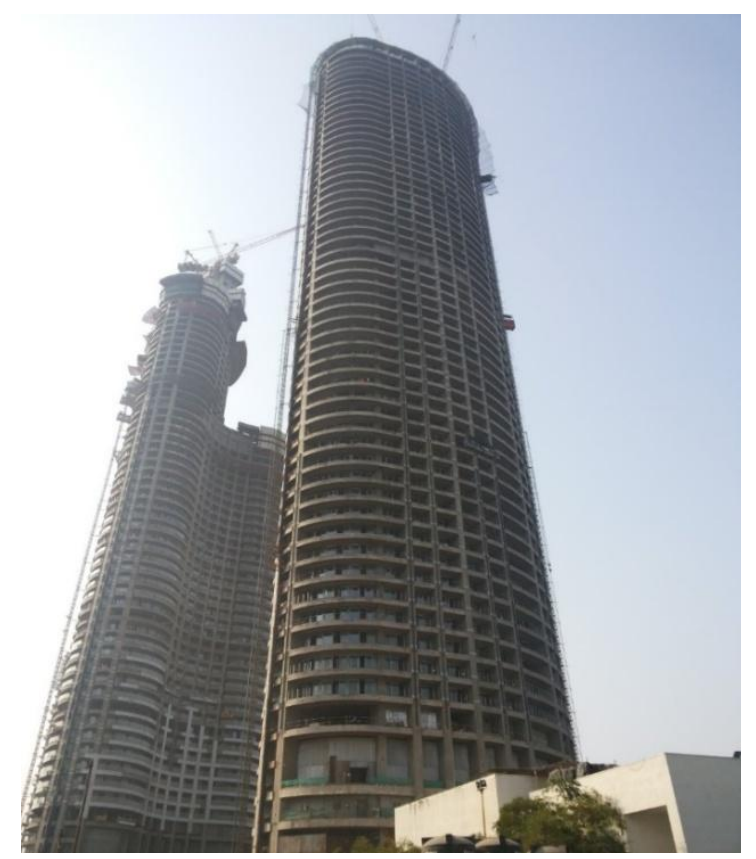

Fig -1: World One Tower, Mumbai

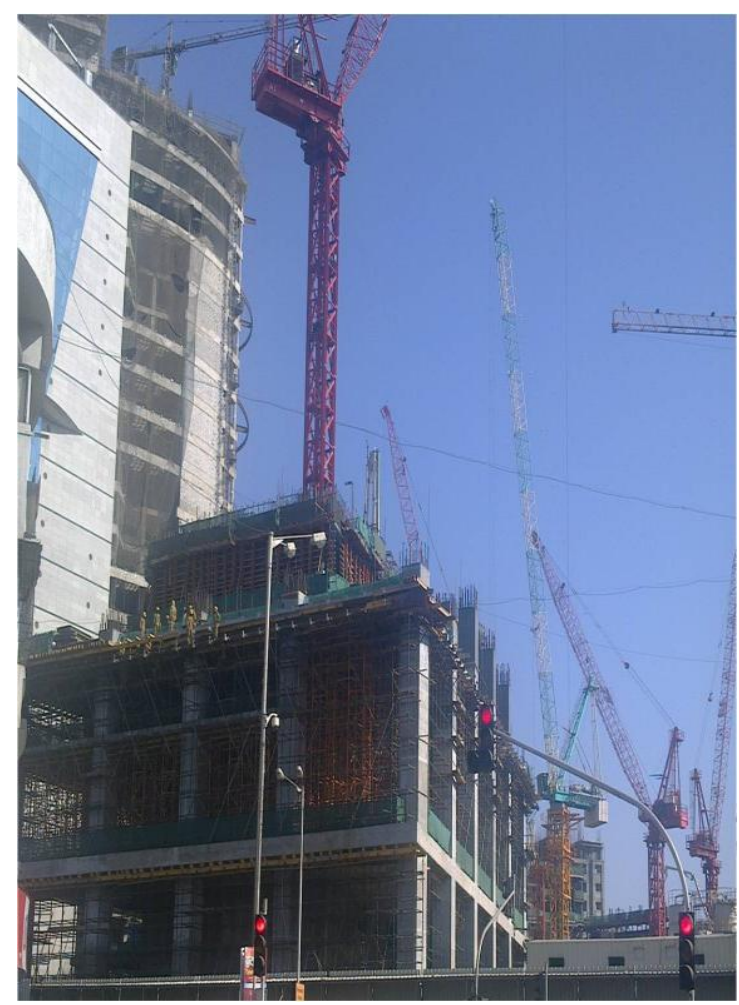

Fig -2: Oasis Tower, Mumbai 


\section{CONCLUSIONS}

- Since the 1980s, high strength concrete has featured increasingly in the construction of tall buildings. This has coincided with growth and development in the use of microsilica generally.

- High strength concrete can reduce the consumption of concrete, providing an opportunity for both cost savings and more sustainable construction

- Microsilica is an integral component in the production of high strength concrete. It increases concrete strength by improving the particle packing of the mixture and by pozzolanic reaction

- Many of the world's tallest buildings, including the BurjKhalifa in Dubai, are constructed using high performance microsilica concrete

- A tripleblend approach to concrete mix design, where Portland cement is blended with microsilica and either fly ash or GGBS, can enable optimal dosage of the cementitious materials, leading to cost savings and improved performance

\section{REFERENCES}

[1] J Moreno, 'High-Performance Concrete: Economic Considerations', Concrete International, March 1998, 68-70

[2] Concrete Society UK, 'Cementitious materials', CS Technical Report No. 74, (Concrete Society UK, 2011)

[3] Bentur, A., Goldman, A., and Cohen, M. D., 1988, 'The Contributions of the Transitions Zone to the Strength of High Quality Silica Fume Concretes' in Proceedings of the Symposium on Bonding in Cementitious Composites, Boston, 1988, ed. S. Mindess and S. P. Shah, V. 114 (Materials Research Society, Pittsburgh, USA, 1988) 97-103.

[4] EMMA program, available at https://www.elkem.com/silicon-materials/highperformance-concrete/ (accessed online $4^{\text {th }}$ July 2016)

[5] A.H.M. Andreassen and J.Andersen, Kolloid Z., 1930,50, 217-228

[6] ASTM C1240-15, 'Standard Specification for Silica Fume Used in Cementitious Mixtures', (ASTM International, USA, 2015)

[7] BS EN 13263-1:2005+A1:2009, 'Silica fume for concrete. Definitions, requirements and conformity criteria', (British Standards International, UK, September, 2009)

[8] IS 15388:2003, 'Silica Fume - Specification', (Bureau of Indian Standards, 2003)

[9] F Chan, W Zhengand A. Kwan. 'Life-cycle carbon footprint and waste generation of high-performance concrete buildings'. In Proceeding of Materials Science and Technology in Engineering Conference, 2009, Hong Kong

[10] M. Thomas, M. Shehata, S Shashiprakash, D Hopkins andK Cail. 'Use of ternary cementitious systems containing silica fume and fly ash in concrete', Cement and Concrete Research, 1999, 29 (4), 1207-1214.

[11] J. Hegger, 'High Strength Concrete for a 186 m High Office Building in Frankfurt, Germany', in Proceedings of Utilization of High Strength Concrete Symposium, Norway, June, 1993 edHoland\&Sellevold, 504-511

[12] M Thomas, K Cail and R Hooton, 'Development and Field Applications of Silica Fume Concrete in Canada: A Retrospective', Canadian Journal of Civil Engineering, 1998, 25(3) 391-400

\section{BIOGRAPHY}

Ben Sealey is a Technical Manager at Elkem Silicon Materials, based in Kristiansand, Norway. He is a Member of the Institute of Concrete Technology. 